\title{
SEROLOGICAL EVIDENCE OF INFECTIOUS BURSAL DISEASE VIRUS INFECTION IN WILD RATS
}

\section{J.O.A. OKOYE and U.E. UCHE}

Faculty of Veterinary Medicine, University of Nigeria, Nsukka, Nigeria

Received April 24, 1985

\begin{abstract}
$0 \mathrm{ko}$ y e J. O. A., U $\mathrm{c} h \mathrm{~h}$ U. E.: Serological Evidence of Infectious Bursal Disease Virus Infection in Wild Rats. Acta Vet. Brno, 55, 1986: 207-209.

A total of 23 wild rats (Rattus rattus) were caught dead by traps set in 4 different poultry farms with history of outbreak of infectlous bursal disease (IBD). The internal. organs were suspended in phosphate buffered saline (PBS) and assayed for IBD precipitins and antigens by agar gel diffusion precipitation test (AGDT). Six samples were positive for precipitins. These observations indicate that IBD virus multiples in wild rats and these rats may play some role in the spread of the disease among poultry farms.
\end{abstract}

Epizootiology, screening, rodents.

Infectious bursal disease (IBD) of chickens was first described in United States of America by Cos 8 r o ve (1962). O n u $n$ wo (1975) confirmed the existence of the disease in Nigerla. Further studies by $N$ a $a t h$ et al. (1978), O n u k o (1978), O $\mathrm{k} \circ \mathrm{ye}$ and $\mathrm{UzO}$ o kw u (1982) showed that IBD is not only endemic but also causes an unusually/hign mortality in Nigeria. But the epizootology of the disease is not well understood. It has been observed that once IBD enters a farm, it reoccurs in subsequent flocks (C $s$ s 1 and Gua 1 a nd 1 1977; $S$ a $m$ e r 8 and Meroz 1977; Thornton 1977; $0 \mathrm{k} \circ \mathrm{ye}$ and $\mathrm{U} z \circ \mathrm{u}$ w 1982). This reoccurrence could be due to the persistence of IBD virus in infected farms ( $1 \mathrm{n} d \mathrm{e} v \mathrm{~g}$ e 1 et al. 1976) due to the physical and chemical properties of the virus ( $\mathrm{e} t \mathrm{e} k$ et al. 1973). The disease primarily affects the domestic fowl $(0 \mathrm{k}$ o y e 1984) but the experimental form has been described in mice by $R 1 \mathrm{n}$ a $1 \mathrm{~d} 1$ et al. (1970), $\mathrm{C} a \mathrm{~mm} a \mathrm{r}$ a et al. (1979) and B e $\mathrm{t}$ e $t \mathrm{t}$ et al. (1980). Not much 1s known about the ability of IBD virus to infect wild rats (Rattus rattus) which commonly Inhablt poultry houses and can act as disease carriers. Some of these rats live in the bush and go into the farms in the night to eat the feeds kept in the feeders and in the stores. Often chicks are eaten by these rats.

\section{Material and Methods}

Over a period of 3 months, 23 wild rats were caught dead with traps set in 4 different farms with history of outbreaks of IBD in chickens. Each rat was eviscerated and the lungs, liver, kidney, heart and spleen were collectively weighed and homogenized with equivalent volume/weight of phosphate buffered saline (PBS). The homogenates were assayed for IBD virus precipitins and antigens in agar gel diffusion precipitation test (AGDT) using the agar and method described by $0 \mathrm{k} O \mathrm{y} e$ and $U \mathrm{z} \circ \mathrm{u} \mathrm{k} u$ (1981). For detection of precipitins, the positive control was known IBD antiserum and negative control was normal serum. In antigen detection, the positive control was a suspension of infected bursa while the negative control was normal bursal suspension. 


\section{Results}

Precipitation lines were obtained between the rat tissue suspension and known IBD virus antigen within 36 hours in 6 samples. Other samples were negative for both IBD viral antigen and precipitin. But the positive controls had positive results and the negative controls were negative.

\section{Discussion}

The observations indicate that wild rats are susceptible to IBD virus infection. The possibility of the infection producing clinical signs and pathological lesions as in suckling mice ( $\mathrm{C} \mathrm{a} \mathrm{m} \mathrm{m} \mathrm{a} \mathrm{r}$ a et al. 1979) is outside the scope of this paper.

The detection of IBD viral precipitins in tissue suspensions has been reported in chickens by I d e (1975), U l b r i c h and Z u r e k (1977) and $O k \circ y e$ (1983). This method was used in this study because it was not possible to catch the rats alive. The method can also be useful in screening other wild mammalian and avian species for IBD virus infection. It is however possible that tissue suspensions may give lower number of positive results than serum samples.

$\mathrm{E} \mathrm{d} \mathrm{g} \mathrm{a} \mathrm{r}$ and $\mathrm{C} \mathrm{h} \circ$ (1976) mentioned that there was no convincing evidence that the presence of rodents was related to the spread of IBD. But the results of this investigation show that IBS virus can multiply in wild rats in sufficient quantities to induce the production of detectable precipitins. It is therefore possible that the rats can discharge the virus in their excrements like faeces and this may lead to spread of IBD among poultry farms. E d g r and C h o (1976) reported that the major means of spread of IBD virus to new areas was by movement of left-over finisher ration (diet) from hoppers on an IBD-farm to a susceptible flock on clean premises. This practice is not common in Nigerian poultry husbandry but IBD has spread to all the 19 states of the country since it was first confirmed.

\section{Serologický prükaz infekce virem infekčni bursitidy u krysy obecné}

V okoli 4 drúbežárských farem s výskytem infekční bursitidy (IB) bylo do pastí odchyceno 23 krys (Rattus rattus). Z jejich orgánu byla pripravena suspenze ve fyziologickém roztoku s fosfátovým pufrem. Ve vzorcich byly stanoveny precipitačn protilátky a antigeny proti IB pomoci difusní precipitace na agarovém gelu. Precipitačn protilátky byly nalezeny $v$ šesti vzorcích. Tyto nálezy ukazuji, že virus infekenń bursitidy se pomnožuje i $v$ organismu krys, které mohou hrát roli $v$ šŕrení tohoto onemocněni mezi drưbežářskými farmami.

\section{Серологическое дохазательство инфехции вирусом инфехционного бурсита} у трысы

В охрестностях 4 птицеводческих ферм с наличием инфехционного бурсита (ИВ) поимали довушхои 23 хрыс (Rattus rattus). Из их органов подготовили суспензию в фияиологическом растворе с фосфатвым буферным раствором. В образцах определяли преципитационные автитела и антигены против ив с помощью диффузионной преципитации на агаровом геле. Преципитационные антитела были обнаружены в шести образцах. Приведенные данные свидетельстбуют о том, что инфехционный бурсит развиваетця тахже в органияме хрыс, которые могут играть роль в распространении данного заболевания на птицеводческих фермах.

\section{References}

BESTETTO, G. - CAMARATA, G. - CAMARATA, M.P. - RAMPIN, T.: Ultrastructural aspects of an encephalomyelitis experimentally produced in mice with the avian infectious bursal agent. Preliminary note. Clin. vet., 103, 1980: 415-421.

CAMARATA, G. - PARODI, M.C. - RAMPIN, T.: Encephalitis in mice due to infectious bursal disease virus. Arch. Vet. Ital., 30, 1979: 119-124. 
CESSI, D. - GUALANDI, G.L.: Infect1ous bursal disease (Gumboro disease) and 1ts control in Italy. Bull. Off. Int. Ep1z., 88, 1977: 255-262.

COSGROVE, A.S.: An apparently new disease of chlckens - avian nephrosis. Avian D18., 6, 1962: 385-389.

EDGAR, S.A. - CHO, Y.: The epizootology of Infectlous bursal disease and prevention of $1 t$ by imunization. Dev. B1ol. Standard, 33, 1976: 349-356.

IDE, P.R.: A comparison of gel diffusion, fluorescent antibody and virus 1solation methods in experimental and natural cases of infectlous bursal disease. Can. J. Comp. Med., 39, 1975: 183-190.

NAWATHE, D.R. - ONUNKWO, O. - SMITH, M.: Serological evidence of Infections with infectlous bursal disease in wild and domestic birds in Nigeria. Vet. Rec., 102, 1978: 444.

OKOYE, J.O.A.: The pathogenicity and pathology of a Nigerian 1solate of infectious bursal disesse virus in chickens. M. Phil. Diss., University of Nigeria, Nsukka. 1983.

OKOYE, J.0.A.: Infectlous bursal disease of chicken. Vet. Bull., 54, 1984: 425-436.

OKOYE, J.0.A. - UZOUKWU, M.: An outbreak of Infectious bursal disease among chickens between 16 and 20 weeks old. Avian D1s., 25, 1981: 1034-1038.

OROYE, J.O.A. - UZOUKWU, M.: Characterization of Nigerian strains of infectipus bursal disease virus of chickens. Clinicopathological manifestations of naturally occurring fleld outbreaks. Bull. Anim. Hlth. Prod. Afr., 30, 1982: 193-197.

ONUNKWO, 0.: An outbreak of infectious bursal disease of chickens in Nigeria. Vet. Rec., 97, 1975: 433.

ONUNKWO, 0.: Problems of Gumboro disease of chickens in Nigerla. J. N1g. Poult. Assoc., 2, 1978: 95-101.

PETEK, M. - D'APRILE, P.N. - CANCELOTTI, F.: Biological and physico-chemical properties of Infectious bursal disease virus (IBVD). Avian Pathol., 2, 1973:135152.

RINALDI, A. - MANDELLI, G. - CESSI, D. - CERVIO, G. - VALERIA, A.: Aetiology of Gumboro disease. II. Pathogenicity of the virus for laboratory animals. 4th Congr. W1d. Vet. Poult. Assoc., Belgrade, 1970, pp. 309-313.

SAMBERG, Y. - MEROZ, M.: Infectlous bursal disease (Gunboro disease) in Israel. Bull. Off. Int. Ep1z., 88, 1977: 271-274.

THORNTON, D.H.: Specifications for Infectlous bursal disease vaccines. Bull. Off. Int. Ep12., 88, 1977: 199-212.

ULBRICH, F. - ZURECK, I.: Agar gel precipitation test for diagnosis of Infectious bursal disease in fowl (Gumboro disease). Mh. Vet. Med., 32, 1977: 588-593.

VINDEVOGEL, H. - GOUFFAX, M. - MEULEMANS, G. - DUCHATEL, J.P. - HALEH, P.: Gumboro disease: distribution and persistence of the virus in inoculated chickens. Study on the transmission of the disease. Avian Pathol., 5, 1976: 31-38. 